\title{
Assessment of Transplanting Date Influence on Processing Tomato (Lycopersicon esculentum Mill.) Production Using The Cropping System Model (CSM)-CROPGRO-Tomato Simulation Model A Case Study for Northeastern Italy
}

\author{
Maha Elsayed ${ }^{\text {a,*}, \text { Mahmoud Medany }}{ }^{\text {b }}$, Gerrit Hoogenboom ${ }^{c}$, Michele Rinaldi ${ }^{\mathrm{d}}$, \\ Stefano Bona ${ }^{\mathrm{e}}$, and Paolo Sambo \\ ${ }^{a}$ Central Laboratory for Agricultural Climate (CLAC) , ${ }^{b}$ Horticulture Research \\ Institute (HRI), Agricultural Research Center (ARC), Ministry of Agriculture \\ and Land Reclamation (MALR), 9 Gamaa st., Giza, Egypt, ' Preeminent Scholar, \\ Institute for Sustainable Food Systems, Agricultural and Biological Engineering, \\ 184 Frazier Rogers Hall, University of Florida, Gainesville, Florida 32611-0570, \\ USA, ${ }^{d}$ Consiglio Per la ricerca e la sperimentazione in agricoltura, Unit di ricerca \\ peri sistemi colturali degli ambienti caldo-aridi (CRA-SCA), Via Celso Ulpiani 5, \\ 70125 Bari,and ${ }^{e}$ Department of Agronomy, Food, Natural Resources, Animals and \\ the Environment (DAFNAE), University of Padova, Viale dell'Università 16, 35020, \\ Legnaro (PD), Italy
}

\begin{abstract}
TALIAN processed tomato has a major dominance at the global level but few studies have been conducted using a cropping systems analysis approach for this crop. The objective of this research was to evaluate the Cropping System Model (CSM)-CROPGRO-Tomato of the DSSAT (Decision Support System for Agrotechnology Transfer) software with experimental data obtained from field studies conducted in Legnaro, northeastern Italy in 2009 and 2010. The experiment encompassed four transplanting dates with ten-day intervals from $22^{\text {nd }}$ March (TD1, 2, 3, and 4), and two processing tomato varieties (Augusto F1 (De Ruiter), and NPT 63 (S \& G)) comparing mulched and non-mulched plots. A comparison of yield for the different transplanting dates showed that earlier transplanting increased yield for both varieties, there was a variation in yield between varieties in both years. Calibration of CSM-CROPGRO-Tomato model using nonmulched data of 2009 showed that index of agreement (d-Stat) between observations and model simulation for different parameters (total dry matter, fruits fresh and dry weight, vegetative dry matter, number of fruits, harvest index and leaf area index) using both varieties ranged from 0.562 to 0.964 at TD1, from 0.915 to 0.992 at TD2, from 0.566 to 0.990 at TD3, and from 0.733 to 0.998 at TD4. Values of d-Stat for model calibration were lower for leaf area index, which ranged from 0.511 to 0.924 . Model calibration using TD1 gave acceptable simulation, whereas it was quite high with the other transplanting dates. CSM-CROPGRO-Tomato model could be used as a decision-making tool helping in regional short term plans.
\end{abstract}

Keywords: DSSAT, Crop simulation, Calibration, Validation, Mulching soil, Rainy season, and Fruit fresh weight.

\section{Introduction}

According to FAO (2009) the top six producers of tomatoes (Lycopersicon esculentum Mill.) in 2009 were China, United States, India, Turkey, Egypt, and Italy, respectively, whereas the annual production in 2009 in the Mediterranean was more than 29.9 million tons, which represents about $21 \%$ of the global production (FAO, 2009).

Italy produces more than 6.4 million tons of tomatoes annually from an area of 117100 ha at an average yield of $54506.4 \mathrm{~kg} \mathrm{ha}^{-1}$ (FAO, 2009). This represents $21.4 \%$ of the

\footnotetext{
*Corresponding author: Tel: +2 01225661384, E-mail addresses: mha1182000@yahoo.com DOI : 10.21608/ejss.2017.504.1067

C2017 National Information and Documentation Center (NIDOC)
} 
Mediterranean production and about $5 \%$ of the global production. Italy dominates the global processed tomato products market (FAO, 2007). The World Processing Tomato Council stated in 2006 that Italy supplied $18 \%$ of the total world production in 2005 for processing tomato, and northern Italy produces more than $40 \%$ of Italy's total production (AMITOM, 2006).

There are only a few models that so far have been used for the simulation of tomatoes under greenhouse and field conditions (Rinaldi et al., 2007), and only a few of them simulate growth, development, and yield as a function of both local weather and soil conditions.

DSSAT is a software suite that contains a collection of independent programs operating together, with the Cropping System Model (CSM) at its core. DSSAT encompasses models for more than 28 different crops based on various crop and soil modules (i.e. CERES, CROPGRO, CROPSIM, SUBSTOR, and CENTURY) with a software that facilitates the evaluation and application of the crop models for different purposes (Hoogenboom et al., 2003). It is a package of cropping system models that includes special programs to create databases on crop experiments (including crop management treatments as well as measurements made on soil and crop in the experiments), on soil parameters and on climatic data. The software helps users with the preparation of these databases and to compare simulated results with observations to give them confidence in the models or to determine if modifications are needed to improve accuracy (Uehara, 1989 and Jones et al., 1998).

In this study, a beta version of DSSAT v4.5 (Hoogenboom et al., 2009) was used to simulate growth, development and yield for tomato using the CSM-CROPGRO-Tomato (Jones et al., 2003).

The CSM-CROPGRO-Tomato model allows for the simulation of tomato growth over a wide range production systems (Scholberg et al., 1997). CROPGRO was created after the earlier experience in adapting SOYGRO to PNUTGRO and BEANGRO (Hoogenboom et al., 1994) based on the idea of one common program with values from files providing information for each species to be modelled. Currently, it simulates ten crops; including seven grain legumes (soybean (Glycine max L. Merr.); peanut (Arachis hypogaea L.); dry

Egypt. J. Soil Sci., Vol. 57, No.4 (2017) bean (Phaseolus vulgaris L.); chickpea; cowpea; velvet bean and faba bean (Vicia faba L.), and non-legumes such as tomato (Lycopersicon esculentum Mill.) (Scholberg et al.,1997 and Boote et al., 1998a, b).

Several models have been developed for tomato to predict different growth and production parameters (Wolf et al., 1986, Bertin \& Gray 1993, Heuvelink \& Marcelis 1993 and Jones et al., 1989). Jones et al. (1991) have developed TOMGRO growth model for greenhouse tomato, but Scholberg et al. (1997) found that TOMGRO did not adequately describe the growth of field-grown tomatoes. Subsequently, Scholberg et al. (1997) adapted the CROPGRO-Peanut model establishing CROPGRO-Tomato model to simulate growth, yield and yield components of the field-grown tomatoes. Modelling the growth of field-grown tomatoes should assist growers and extension workers throughout the world to outline optimal crop management strategies for specific locations and production systems (Scholberg et al., 1997).

The main objective of this study was to simulate growth, yield, and yield components of the CSM-CROPGRO-Tomato model for field grown processing tomato transplanted at different transplanting dates and associated weather conditions. The experiments were conducted in northeastern Italy, representing typical conditions for processing tomatoes.

\section{Materials and Methods}

\section{Experiment description}

Two open-field experiments were conducted in 2009 and 2010, to obtain observed datasets ready to be used in calibration and validation phases of the CSM-CROPGRO-Tomato model, respectively. The experiment was conducted at the Experimental Farm "L. Toniolo" of Padova University $\left(45^{\circ} 21^{\prime} \mathrm{N} ; 11^{\circ} 58^{\prime} \mathrm{E}\right)$ in Veneto region, northeastern Italy. In 2009, calibrating the model was done with the data for two processing tomato varieties (Lycopersicon esculentum Mill.) were used in the experiment, which were Augusto F1 (AUG) from De Ruiter company; and NPT 63 (NPT) from S\&G Company. Validating the model was done through both varieties which were cultivated in 2010 as two examples of a vigor variety (NPT) and a moderate growth variety (AUG). 
Seeds were sown individually in foam trays with holes' dimensions of $2 \times 2 \mathrm{~cm}^{2}$ using peat moss growing media. They were placed in a warm metal-glass greenhouse starting at $11^{\text {th }}$ of March in 2009 and at $23^{\text {rd }}$ of March in 2010 at ten-day intervals between the four sowing dates, then planted trays were moved to a cool plastic greenhouse when plantlets had 2-3 true leaves (about 16 days after sowing). Average greenhouse environment temperatures during the four sowing dates were 18.9, 19.6, 21.3, and 22 ${ }^{\circ} \mathrm{C}$, respectively. Manual sprinkling irrigation was applied for the plantlets till they had two true leaves then fertigation (Pimpini et al., 2007) was applied alternatively with irrigation. At 40 days after sowing the plantlets were transplanted in the open field. This resulted in four different transplanting dates (TD1, 2, 3, and 4) also at 10 days' intervals. The open field experiment was started on $21^{\text {st }}$ of April and was finished on $2^{\text {nd }}$ of September in 2009, whereas it was started on $29^{\text {th }}$ of April and was finished on $30^{\text {th }}$ of August in 2010.
Two agronomic practices including mulched and non-mulched soil were used. Soil was mulched using a black poly-ethylene plastic layer. The experimental area was $768 \mathrm{~m}^{2}$ in size and was divided using a split-split plot design. The two mulching managements were the main treatments, then transplanting dates as sub-plots and varieties as sub-sub-plots. The experiment consisted of three replicates. The inter-row distance was $40 \mathrm{~cm}$ and the in-row distance was $30 \mathrm{~cm}$. These distances were used according to the industrial field grown tomato practices in the region under study. A drip irrigation system was used to irrigate the different blocks and the amount of irrigation water was recorded for each plot using flow meters. The total amounts of fertilizers applied were $150 \mathrm{~kg}$ $\mathrm{ha}^{-1}$ of N, $100 \mathrm{~kg} \mathrm{ha}^{-1}$ of $\mathrm{P}_{2} \mathrm{O}_{5}$, and $120 \mathrm{~kg} \mathrm{ha}^{-1}$ of $\mathrm{K}_{2} \mathrm{O}$ (Rinaldi et al., 2007) at the beginning of each transplanting process. Samples of biomass were taken at two weeks' interval starting at one month after transplanting. Sample intervals and main operations in the two soil management treatments can be summarized as illustrated in Fig. 1 .

Mulched

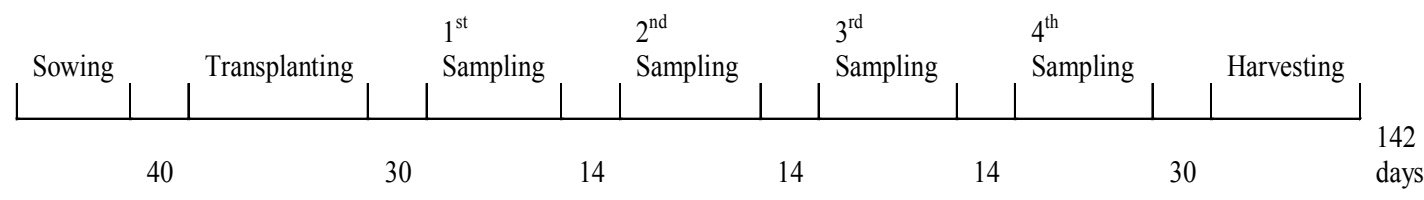

Non-mulched

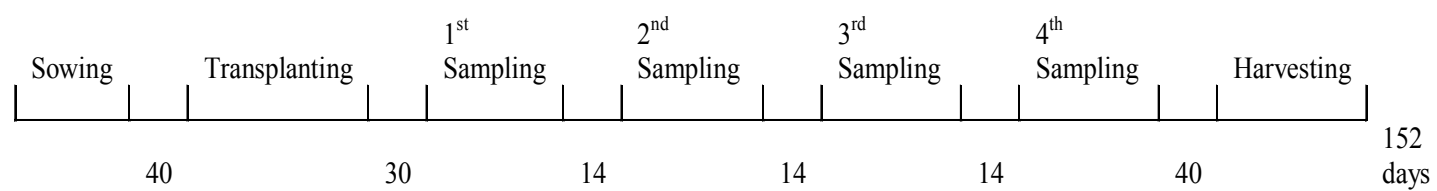

Fig. 1. Representation of sampling structure during the tomato plant cycle ( Cycle days here are give in photothermal days)

The parameters collected included (1) daily meteorological observations, (2) soil physical and chemical characteristics, (3) vegetative growth and development, and (4) yield. The meteorological observations included maximum and minimum temperature, precipitation, and total solar radiation. The soil parameters included chemical $(\mathrm{pH}, \mathrm{EC}$, total $\mathrm{N}$, nitrate, and total organic carbon) and physical (soil texture, bulk density, and CEC) characteristics. The vegetative parameters included fresh and dry biomass/ plant, SPAD/plant, leaf area/plant, number of leaves/plant, canopy height, fresh and dry fruit weight $/$ plant, and number of fruits $/ \mathrm{m}^{2}$. The yield parameters included fresh and dry biomass/plant, fresh and dry fruit weight/plant, and total number of fruits $/ \mathrm{m}^{2}$. These measurements were obtained in accordance with the minimum datasets required to be run and evaluate crop models (Hunt et al., 2001).

Data for fresh and dry yield were analyzed statistically using Duncan test (Statgraphics program) at 0.05 probabilities.

\section{Model description}

Detailed information about seedlings of each variety at transplanting time was used as initial characteristics in FileX, and they are explained in Table 1. Seedlings were transplanted in the open field with 10 days' interval between the four transplanting dates (TD1, 2, 3, and 4).

Egypt. J. Soil Sci., Vol. 57, No.4 (2017) 
TABLE 1. Characteristics and nursery conditions of tomato seedlings at transplanting (TD: transplanting date, AUG \& NPT: processing tomato varieties)

\begin{tabular}{|c|c|c|c|c|c|}
\hline \multirow{2}{*}{ Characteristics } & \multirow{2}{*}{ TD } & \multicolumn{2}{|c|}{ AUG } & \multicolumn{2}{|c|}{ NPT } \\
\hline & & 2009 & 2010 & 2009 & 2010 \\
\hline \multirow{4}{*}{ Seedling dry weight (g/seedling) } & 1 & 5.54 & 5.55 & 10.6 & 10.7 \\
\hline & 2 & 13.9 & 28.4 & 23 & 23.2 \\
\hline & 3 & 18.8 & 12.5 & 21.7 & 17.9 \\
\hline & 4 & 18 & 19 & 26.9 & 18.8 \\
\hline \multirow{4}{*}{$\begin{array}{l}\text { Age (days from sowing to } \\
\text { transplanting) }\end{array}$} & 1 & 24 & 38 & 24 & 38 \\
\hline & 2 & 32 & 46 & 32 & 46 \\
\hline & 3 & 31 & 38 & 31 & 38 \\
\hline & 4 & 31 & 38 & 31 & 38 \\
\hline \multirow{4}{*}{$\begin{array}{c}\text { Average Temperature during } \\
\text { nursery period }\left({ }^{\circ} \mathrm{C}\right)\end{array}$} & 1 & 23.4 & 18.9 & 23.4 & 18.9 \\
\hline & 2 & 22.4 & 19.6 & 22.4 & 19.6 \\
\hline & 3 & 25.6 & 21.3 & 25.6 & 21.3 \\
\hline & 4 & 34.2 & 22 & 34.2 & 22 \\
\hline \multirow{4}{*}{$\mathbf{N}^{0}$ plants per hill } & 1 & 1 & 1 & 1 & 1 \\
\hline & 2 & 1 & 1 & 1 & 1 \\
\hline & 3 & 1 & 1 & 1 & 1 \\
\hline & 4 & 1 & 1 & 1 & 1 \\
\hline \multirow{3}{*}{ Sprout length (cm) } & 1 & 15 & 13 & 15 & 15 \\
\hline & 2 & 15 & 17 & 15 & 20 \\
\hline & $\begin{array}{l}3 \\
4\end{array}$ & $\begin{array}{l}15 \\
20\end{array}$ & $\begin{array}{l}13 \\
15\end{array}$ & 15 & $\begin{array}{l}15 \\
17\end{array}$ \\
\hline
\end{tabular}

- Use of the model

In this study, the CSM-CROPGROTomato model was evaluated using the nonmulched experimental datasets, which was the environmental condition that was used for initial model development. Experimental data were adjusted and some of them were calculated to fit model format. Compiled data sets, collected biweekly, were entered the time course data file (FileT) and the final compiled data set was entered in the summary data file (FileA). The experimental management details were entered in the experimental details file (FileX) using DSSAT V4.5 standardized format (Hoogenboom et al., 2009). Soil profile descriptions for the experimental location were added to SOIL.SOL file of the DSSAT shell. Information about soil analysis of the location under study was prepared as a soil profile input in the standard soil profiles file. The profile was divided into 5 levels; each level represents $20 \mathrm{~cm}$ of soil depth (Table 2). For each soil level, analysis was made, and in accordance with those analysis, the model could calculate and provide other characteristics such as drained upper limit, saturation, bulk density $\left(\mathrm{g} . \mathrm{cm}^{3}\right)$, saturation hydraulic conductivity $(\mathrm{cm} / \mathrm{h})$, and root growth factor (from 0 to 1 ). Daily weather data set collected for the location was placed in the weather data files (FileW). Weather data for both 2009 and 2010 years were formed in the weather format. The minimum weather parameters for the model were provided which are: solar radiation $\left(\mathrm{MJ} \mathrm{m}^{-2}\right)$, minimum temperature $\left({ }^{\circ} \mathrm{C}\right)$, maximum temperature $\left({ }^{\circ} \mathrm{C}\right)$, and precipitation $(\mathrm{mm})$. Monthly averages for both years are shown in Fig. 2.

\section{- Validation of the model}

There are different statistic indexes that comes with the model output files, including, the normalized root mean square error (RMSE) as explained by Loague and Green (1991), and the Index of agreement (d-Stat, which gives values between 0-1) as described by Willmott (1982) and Willmott et al. (1985). They were the two indexes used during validation stages.

Using the sensitivity analysis option of the model, the cultivar coefficients of the two varieties were adjusted by minimizing RMSE values between observed and simulated flowering and 
maturity dates, vegetative growth, yield and yield components (Table 3 and 4). Correlation analysis for harvest index between observed and simulated output values were obtained using the standard error option of the "Excel- Microsoft" program.

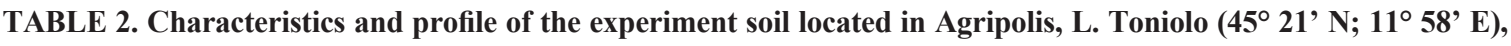
Italy

\begin{tabular}{|c|c|c|c|c|c|c|c|}
\hline Soil classification & \multicolumn{7}{|c|}{ Loamy } \\
\hline Color & \multicolumn{7}{|c|}{ Brown } \\
\hline Drainage & \multicolumn{7}{|c|}{ Well } \\
\hline Slope & \multicolumn{7}{|c|}{3} \\
\hline Runoff potential & \multicolumn{7}{|c|}{ Relatively low } \\
\hline Fertility factor & \multicolumn{7}{|c|}{1} \\
\hline Soil Profile depth $(\mathrm{cm})$ & $\mathbf{0}$ & 20 & 40 & 80 & 100 & 120 & 180 \\
\hline Clay $(\%)$ & $15.4-18.6$ & $15.4-18.6$ & $15.5-18.6$ & $15.6-17.4$ & 14.8 & 18.4 & 28.7 \\
\hline Silt (\%) & $41.3-46.6$ & $41.3-46.6$ & $41.3-46.5$ & $44.2-47.4$ & 50.0 & 57.7 & 52.8 \\
\hline Organic carbon $(\%)$ & $1.2-1.8$ & $1.1-1.6$ & $1.1-1.4$ & 0.7 & 0.2 & 0.7 & 0.2 \\
\hline $\mathrm{pH}$ in water & $8.0-8.4$ & $8.0-8.3$ & $8.0-8.3$ & $8.0-8.4$ & $8.0-8.4$ & 8.0 & 8.0 \\
\hline CEC & 14.8 & 14.8 & 14.8 & 14.8 & 14.8 & 14.8 & 14.8 \\
\hline
\end{tabular}

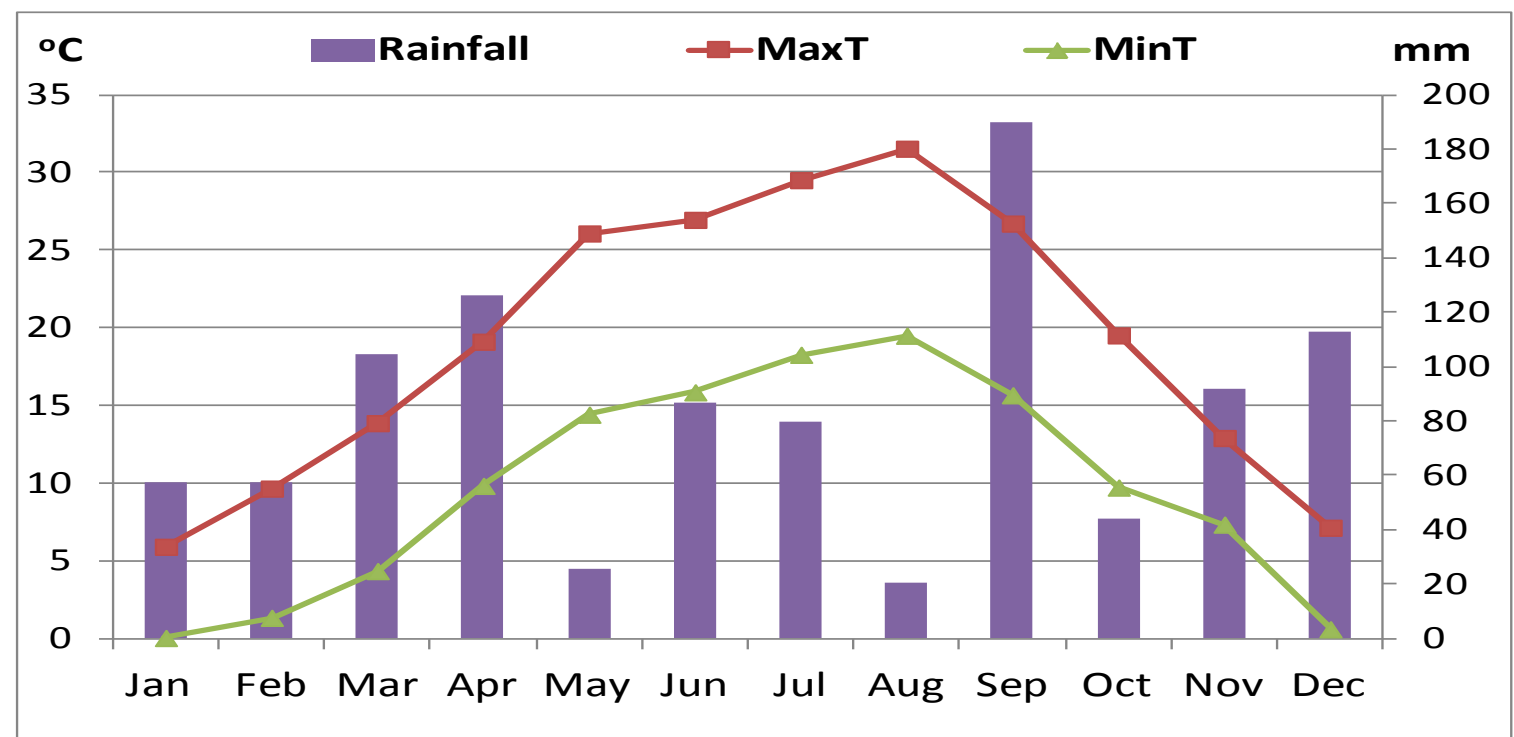

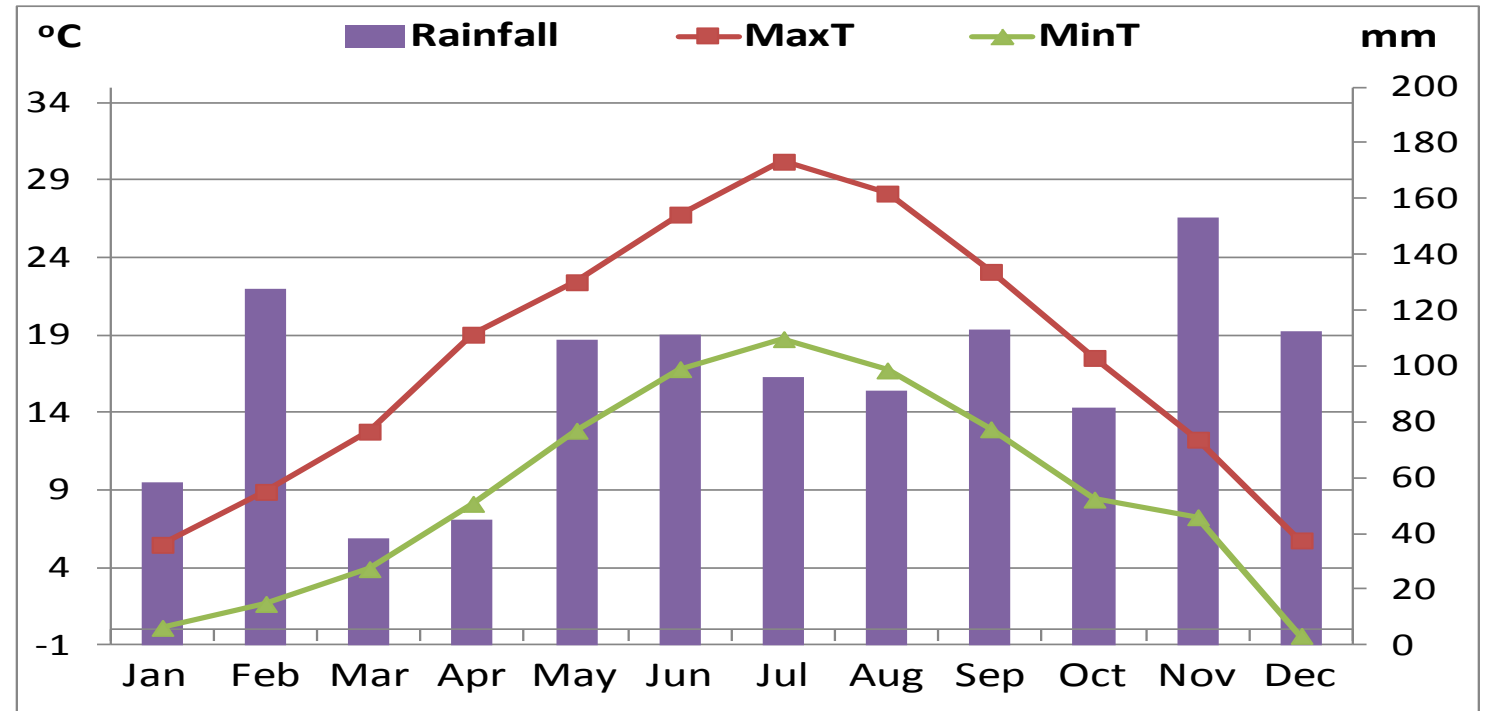

Fig. 2. Weather conditions in experimental grown processing tomato seasons of 2009 and 2010 
TABLE 3. Cultivar coefficients that were modified during calibration phase of the CSM-CROPGRO-Tomato model for the AUG and NPT tomato varieties under study (TOMGRO045.CUL file)

\begin{tabular}{|c|c|c|c|c|}
\hline \multirow{2}{*}{\multicolumn{2}{|c|}{ Cultivar Coefficient }} & \multirow{2}{*}{$\begin{array}{l}\text { Default } \\
\text { values }\end{array}$} & \multicolumn{2}{|c|}{$\begin{array}{l}\text { Calibrated } \\
\text { values }\end{array}$} \\
\hline & & & AUG & NPT \\
\hline 1. & $\begin{array}{l}\text { EM-FL: Time between plant emergence and flower appearance (R1) } \\
\text { (photothermal days) }\end{array}$ & 23 & 23 & 23 \\
\hline 2. & FL-SH: Time between first flower and first pod (R3) (photothermal days) & 8 & 8 & 8 \\
\hline 3. & FL-SD: Time between first flower and first seed (R5) (photothermal days) & 17 & $\underline{14}$ & $\underline{14}$ \\
\hline 4. & $\begin{array}{l}\text { SD-PM: Time between first seed (R5) and physiological maturity (R7) } \\
\text { (photothermal days) }\end{array}$ & 50 & $\underline{38}$ & $\underline{38}$ \\
\hline 5. & $\begin{array}{l}\text { FL-LF: Time between first flower (R1) and end of leaf expansion } \\
\text { (photothermal days) }\end{array}$ & 50 & $\underline{42}$ & $\underline{42}$ \\
\hline 6. & $\begin{array}{l}\text { LFMAX: Maximum leaf photosynthesis rate at } 30^{\circ} \mathrm{C}, 350 \mathrm{vpm} \mathrm{CO}_{2} \text {, and } \\
\text { high light }\left(\mathrm{mg} \mathrm{CO}_{2} \mathrm{~m}^{-2} \mathrm{~s}^{-1}\right)\end{array}$ & 1.36 & 1.36 & 1.36 \\
\hline 7. & $\begin{array}{l}\text { SLAVR: Specific leaf area of cultivar under standard growth conditions }\left(\mathrm{cm}^{2}\right. \\
\left.\mathrm{g}^{-1}\right)\end{array}$ & 350 & $\underline{200}$ & $\underline{220}$ \\
\hline 8. & SIZLF: Maximum size of full leaf (three leaflets) $\left(\mathrm{cm}^{2}\right)$ & 300 & $\underline{170}$ & $\underline{190}$ \\
\hline 9. & WTPSD: Maximum weight per seed (g) & 0.0040 & $\underline{0.0025}$ & $\underline{0.0030}$ \\
\hline 10. & $\begin{array}{l}\text { SFDUR: Seed filling duration for pod cohort at standard growth conditions } \\
\text { (photothermal days) }\end{array}$ & 25 & $\underline{20}$ & 25 \\
\hline 11. & $\begin{array}{l}\text { PODUR: Time required for cultivar to reach final pod load under optimal } \\
\text { conditions (photothermal days) }\end{array}$ & 42 & 42 & 42 \\
\hline 12. & $\begin{array}{l}\text { THRSH: Threshing percentage. The maximum ratio of }(\mathrm{seed} /(\mathrm{seed}+\mathrm{shell})) \text { at } \\
\text { maturity causes seed to stop growing as their dry weight increases until the } \\
\text { shells are filled in a cohort. }\end{array}$ & 9.2 & 9.2 & 9.2 \\
\hline
\end{tabular}

TABLE 4. Species coefficients that were modified during calibration phase of the CSM-CROPGRO-Tomato model for the four tomato varieties under study (TOMGRO045.SPE file) (It is already done in other studies, also to guide the model developer for a possible change leading to better simulation). Species coefficients are not supposed to be changed; justify.

Species Coefficient

XLeaf: 0.0-6.1-8.3-10.3-12.3-14.6-16.9-18.4-19.5 22.1

1. Vegetative partitioning parameters

YLeaf: 0.40-0.45-0.65-0.70-0.70-0.70-0.70-0.70-0.600.60

YStem: $0.30-0.25-0.20-0.20-0.20-0.20-0.20-0.20-$ $0.30-0.30$
Calibrated values

XLeaf: 0.0-16.1-17.3-20.3-22.3-24.6-26.928.4-29.5-29.1

YLeaf: 0.45-0.45-0.58-0.55-0.62-0.58-0.55$0.52-0.51-0.47$

YStem: 0.3-0.3-0.37-0.31-0.35-0.39-0.34$0.37-0.39-0.34$

2. Leaf growth parameters

- FINREF: The specific leaf area $\left(\mathrm{cm}^{2} \mathrm{~g}^{-1}\right)$ of leaves at plant emergence, scaled via SLAVR

- SLAREF: The specific leaf area $\left(\mathrm{cm}^{2} \mathrm{~g}^{-1}\right)$ of the standard reference cultivar at peak early vegetative phase, under optimum temperature, water, and light.

- SLAMAX: Maximum specific leaf area $\left(\mathrm{cm}^{2} \mathrm{~g}^{-1}\right)$

- SLAMIN: Minimum specific leaf area $\left(\mathrm{cm}^{2} \mathrm{~g}^{-1}\right)$

- YVREF(1-6): Respective maximum leaf area $\left(\mathrm{cm}^{2}\right.$ plant $^{-1}$ ) at corresponding $\mathrm{V}$ stage, part of possible limiting leaf area expansion for first (VSSINK) nodes

- YSLATM(1-5): Relative temperature effect on specific $\quad 0.48-0.48-0.48-0.50-0.50$

leaf area of newly-formed leaves $\left(\mathrm{cm}^{2} \mathrm{~g}^{-1}\right)$

$15.4-28.1-83.4-210.0-340.0-500.0$
$15.4-128.1-300.4-500.0-$ $1000.0-2000.0$

$0.50-0.60-0.90-1.00$ 1.00 


\section{Results}

\section{Experimental findings}

The comparison of plant behavior in 2009 with or without mulching showed that mulching the soil significantly enhanced yield of both varieties under study giving $70.70 \mathrm{t} \mathrm{ha}^{-1}$ fresh weight and $3.11 \mathrm{t} \mathrm{ha}^{-1}$ dry weight using mulch and $37.91 \mathrm{t} \mathrm{ha}^{-1}$ fresh weight and $1.68 \mathrm{tha}^{-1}$ dry weight without using it (Table 5). This effect of mulching the soil could be due to the increased soil water retention and soil temperature at the plant root zone, which ameliorate root growth development but mainly on protecting the plant from weeds competition. Comparing yield of the two different tomato varieties we can see that NPT had significantly the best performance $(65.86 \mathrm{t}$ $\mathrm{ha}^{-1}$ fresh and $2.90 \mathrm{t} \mathrm{ha}^{-1}$ dry) followed by AUG (49.18 $\mathrm{t} \mathrm{ha}^{-1}$ and $2.17 \mathrm{t} \mathrm{ha}^{-1}$ dry). This was due to different genetic characteristics of each variety which gave vigor vegetative growth for NPT variety compared with AUG variety. There were no significant differences between yield obtained from both varieties transplanted at different transplanting dates in both fresh and dry matter, which indicate that changing transplanting date in the range considered (from April 14 to May 25, 2009) didn't reflect different weather conditions on the plants were exposed to.

TABLE 5. Total fresh and dry weight (FW, DW) of tomato plants yield in years 2009 and 2010

\begin{tabular}{|c|c|c|c|c|}
\hline & & & & \\
\hline & & & & \\
\hline & FW & DW & FW & DW \\
\hline & & & & \\
\hline Mulch (N & & & & \\
\hline Without & $37.91 \mathrm{~b}$ & $1.68 \mathrm{~b}$ & 106.33 & 5.25 \\
\hline With & $70.70 \mathrm{a}$ & $3.11 \mathrm{a}$ & 115.60 & 6.34 \\
\hline Planting & & & & \\
\hline TD1 & 51.11 & 2.31 & 157.26 & $8.48 \mathrm{a}$ \\
\hline TD2 & 57.36 & 2.54 & 126.72 & $6.74 \mathrm{ab}$ \\
\hline TD3 & 53.93 & 2.35 & 102.61 & $5.05 \mathrm{~b}$ \\
\hline TD4 & 54.81 & 2.40 & 59.11 & $2.99 \mathrm{c}$ \\
\hline $\operatorname{Var}(\mathrm{V})$ & & & & \\
\hline AUG & $49.18 \mathrm{~b}$ & $2.17 \mathrm{~b}$ & $99.37 \mathrm{~b}$ & $4.94 \mathrm{~b}$ \\
\hline NPT & $65.86 \mathrm{a}$ & $2.90 \mathrm{a}$ & $123.19 \mathrm{a}$ & $6.69 \mathrm{a}$ \\
\hline Interactic & & & & \\
\hline $\mathrm{MxP}$ & ns & ns & ns & ns \\
\hline $\mathrm{MxV}$ & ns & ns & * & * \\
\hline PxV & ns & ns & ns & ns \\
\hline $\mathrm{MxPxV}$ & * & $*$ & ns & ns \\
\hline
\end{tabular}

In 2010, the yield under both mulched and nonmulched soil conditions didn't vary significantly in both fresh and dry weight. Comparing fresh yield at different transplanting dates, there were no significant differences among them, whereas the dry weight varied significantly giving better yield at TD1 (8.48 $\left.\mathrm{t} \mathrm{ha}^{-1}\right)$, TD2 (6.74 $\left.\mathrm{t} \mathrm{ha}^{-1}\right)$, TD3 (5.05 $\left.\mathrm{t} \mathrm{ha}^{-1}\right)$ more than TD4 (2.99 $\left.\mathrm{t} \mathrm{ha}^{-1}\right)$. That indicates anticipation of transplanting date has a positive effect on plant growth, development and yield consequently. For the comparison between AUG and NPT varieties, there were significantly better fresh and dry yield for NPT variety (123.19 $\mathrm{t} \mathrm{ha}^{-1}$ fresh and $6.69 \mathrm{t} \mathrm{ha}^{-1}$ dry) than AUG variety
(99.37 $\mathrm{t} \mathrm{ha}^{-1}$ fresh and $4.94 \mathrm{t} \mathrm{ha}^{-1}$ dry). That result confirmed the result of the previous year favoring NPT variety under different conditions. Looking at the interaction between factors affected yield, we can find a significant effect of the combination between mulching and variety. This gave better results for NPT variety under mulching conditions compared with AUG variety under the same conditions, and both are better than plants under non-mulched conditions.

\section{Model outputs}

On the four sampling dates were taken during field experiment period, accumulation 
of the above ground part of tomato plants was measured to evaluate the performance of CSMCROPGRO-Tomato model. For the two varieties used in spring growing seasons of 2009 and 2010, we could arrive to acceptable matching levels between observed values from the field and model simulation values. The main statistical indices used to evaluate the model are reported.

\section{- Total dry matter accumulation}

Comparing the simulated vs. observed values for total dry matter accumulation of AUG plants in 2009 we found that model d-Stat of data calibration values between simulated and observed values at four different transplanting dates for AUG variety were $0.809,0.989,0.961$ and 0.990 , respectively. RMSE values at different transplanting dates for AUG variety were 771,
244.8, 431, and $312.2 \mathrm{~kg} \mathrm{ha}^{-1}$, respectively (Fig. 3). NPT variety data calibration had better simulation giving $0.923,0.965,0.926$ and 0.990 of d-Stat values; and giving 665.8, 575.6, 789.6 and $315.1 \mathrm{~kg} \mathrm{ha}^{-1}$ as RMSE values for TD1, 2, 3 and 4, respectively (Fig. 3). RMSE values for NPT variety were higher than AUG variety as it gave higher total plant dry matter (Fig. 3). At the first transplanting date, the matching between simulated and observed weight was high at the beginning of growing cycle after transplanting, then it was slightly overestimated near to the end of the growing cycle. This could be due to unfavorable weather conditions at transplanting time and the short period after, which is necessary for the plant to hold on and continue till the end of its life cycle. The model could simulate total dry matter accumulation at other three transplanting dates.

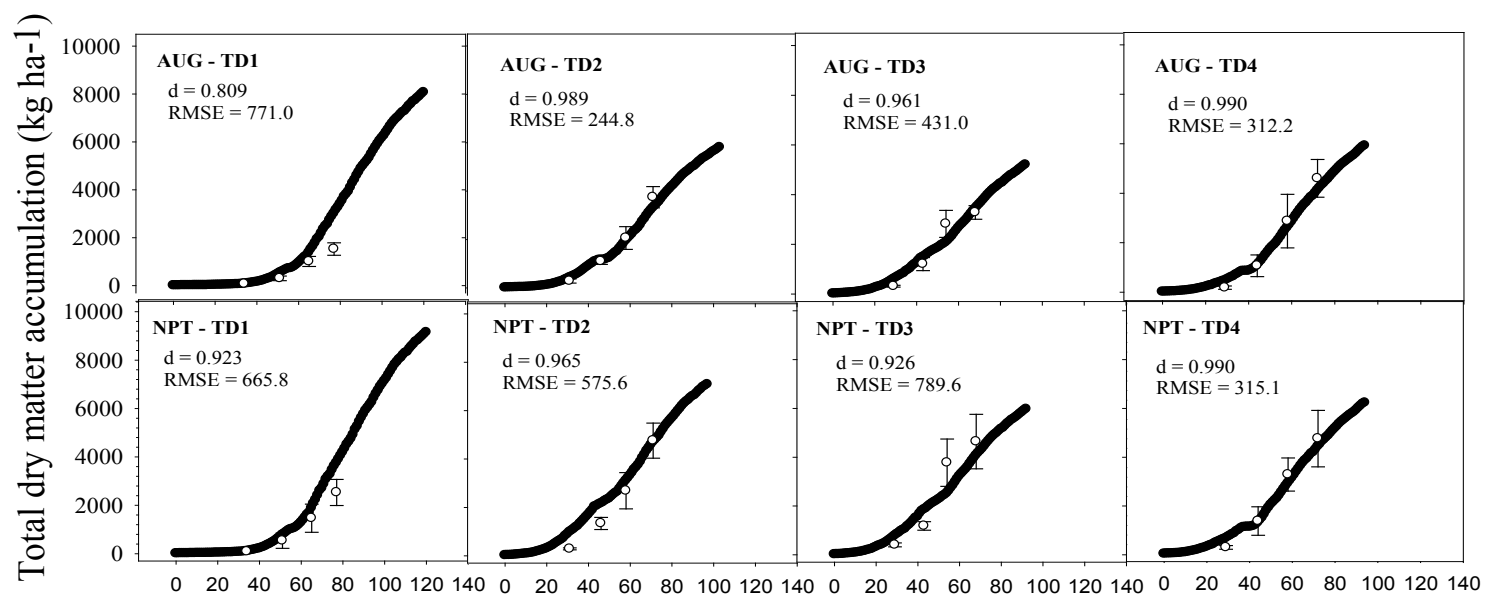

Days after transplanting

- Simulated

- Observed

Fig. 3. CSM-CROPGRO-Tomato model simulation of the total plant biomass during growing cycle of the four processing Tomato varieties under conditions of the four different transplanting dates in 2009.

In 2010, AUG variety validated data at the first three transplanting dates gave $0.931,0.950$ and 0.931 , respectively; and RMSE values at them were 1239,1045 and $1325 \mathrm{~kg} \mathrm{ha}^{-1}$, respectively (Figure 4). At TD4, simulation was much higher than the observed values especially at the end of the growing cycle $(0.626$ of d-Stat and $2494 \mathrm{~kg}$ $\mathrm{ha}^{-1}$ of RMSE). NPT variety validated data had similar simulation to AUG variety giving 0.947 , $0.987,0.959$ and 0.691 of d-Stat values; and giving $1135.1,658.4,1132.9$ and $2675.7 \mathrm{~kg} \mathrm{ha}^{-1}$ as RMSE values for TD1, 2, 3 and 4, respectively (Figure 4). Reduction of d-Stat values at the
TD3 and TD4 was due to peronospora infection which attacked the plants, in addition to, the thunder storm that attacked the field during the month before end of the growing cycle. These two problems caused losses in the broken and weak shoots and cuts in some leaves and fruits, although, plants recovered and continued till the end of their lifecycle (Fig. 4). The model could simulate total dry matter accumulation at the other three transplanting dates with d-Stat values near to the optimal value of 1 and low RMSE values.

Egypt. J. Soil Sci., Vol. 57, No.4 (2017) 


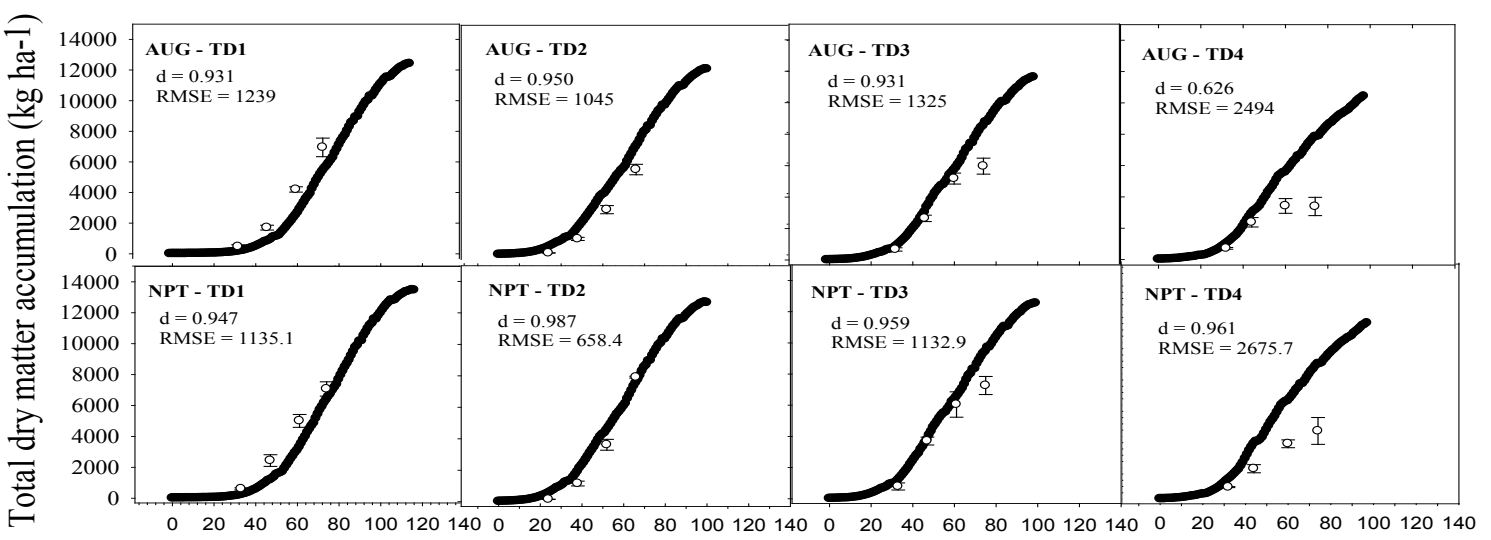

Days after transplanting

- $\quad$ Simulated

$\circ \quad$ Observed

Fig. 4. CSM-CROPGRO-Tomato model simulation of the total plant biomass during growing cycle of AUG and NPT processing Tomato varieties under conditions of the four different transplanting dates in 2010

- Fruits fresh weight accumulation

Fruits fresh weight is a new evaluating parameter was added in the 4.5 version of DSSAT model to evaluate the actual fresh yield of tomato plants. Weather conditions, agronomic practices, and variety genetic characteristics affect this parameter. Figure 5 shows that fruit yield in 2009 data calibrated for AUG variety simulated well by the model under TD2, 3 and 4; giving excellent values for d-Stat $(0.938,0.991$ and 0.989, respectively) and relatively low RMSE values (8051, 2755 and $4163 \mathrm{~kg} \mathrm{ha}^{-1}$, respectively). Simulation accuracy for yield at TD1 (0.725 for
d-Stat, and $6713 \mathrm{~kg} \mathrm{ha}^{-1}$ for RMSE) was lower than the other transplanting dates, as model prediction is less effective at low air temperature. NPT variety had better simulation giving 0.898 , $0.960,0.937$ and 0.998 of d-Stat values; and giving 5976.6, 9233.3, 10270.0 and $1619.7 \mathrm{~kg} \mathrm{ha}^{-1}$ as RMSE values for TD1, 2, 3 and 4, respectively (Fig. 5). Having acceptable matches between observed and simulated yield even by changing the transplanting dates confirmed model ability to predict tomato plants development and yield under open field conditions.

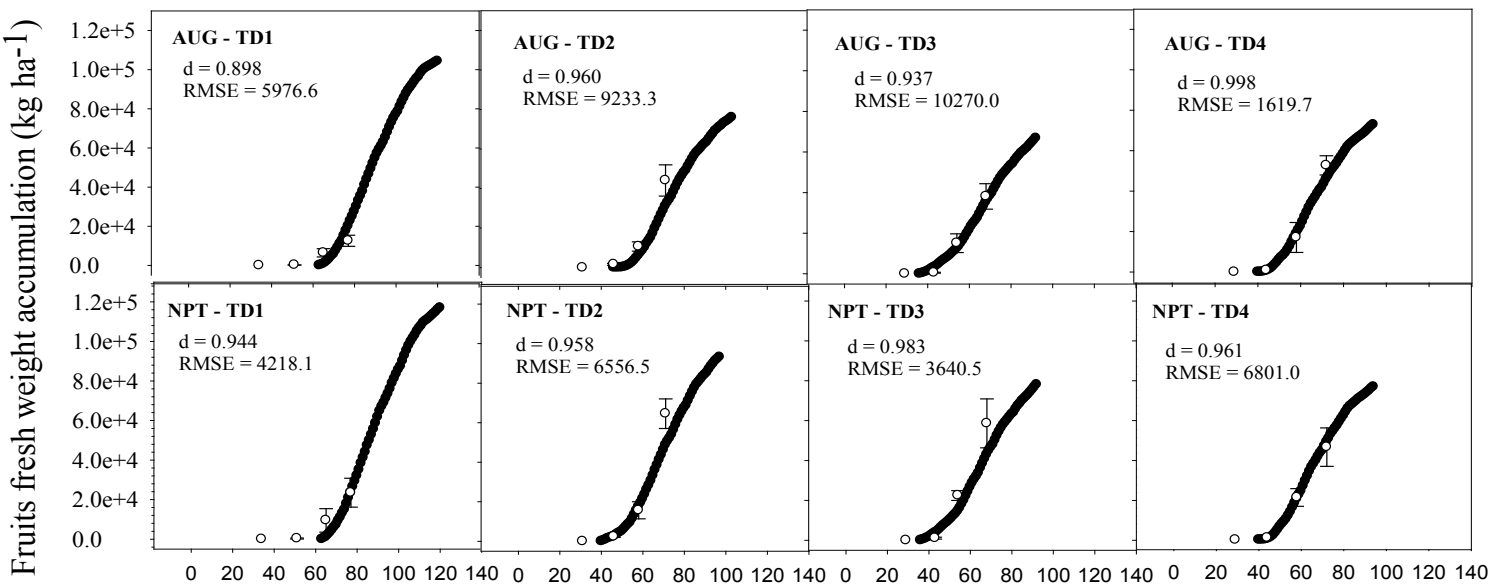

Days after transplanting

- Simulated

- Observed

Fig. 5. Simulated and observed fresh fruits weight accumulation (FFW) for AUG and NPT processing tomato varieties at the four different transplanting dates during the spring 2009 growing season. 
In the spring season of 2010 validation data, fruit yield simulated well by the model for AUG variety under TD2 and 3 (Fig. 6); giving excellent values for d-Stat ( 0.997 and 0.978 , respectively) and relatively low RMSE values (2194 and 7910 $\mathrm{kg} \mathrm{ha}^{-1}$, respectively). Simulation accuracy for yield at TD1 (0.612 for d-Stat, and $38501 \mathrm{~kg} \mathrm{ha}^{-1}$ for RMSE) was low compared to other transplanting dates, as model prediction is less effective at low air temperature. Simulation at TD4 was over than observed one $(0.570$ of d-Stat and $32475 \mathrm{~kg}$ $\mathrm{ha}^{-1}$ of RMSE) at the end of the growing cycle due to peronospora infection and thunder storm that attacked plants during the last month of the growing cycle. NPT variety had similar simulation to AUG variety giving $0.570,0.981,0.997$ and 0.587 of d-Stat values; and giving 35711.9, 6200.3, 3415.8 and $36749.6 \mathrm{~kg} \mathrm{ha}^{-1}$ as RMSE values for TD1, 2, 3 and 4, respectively (Fig. 6).

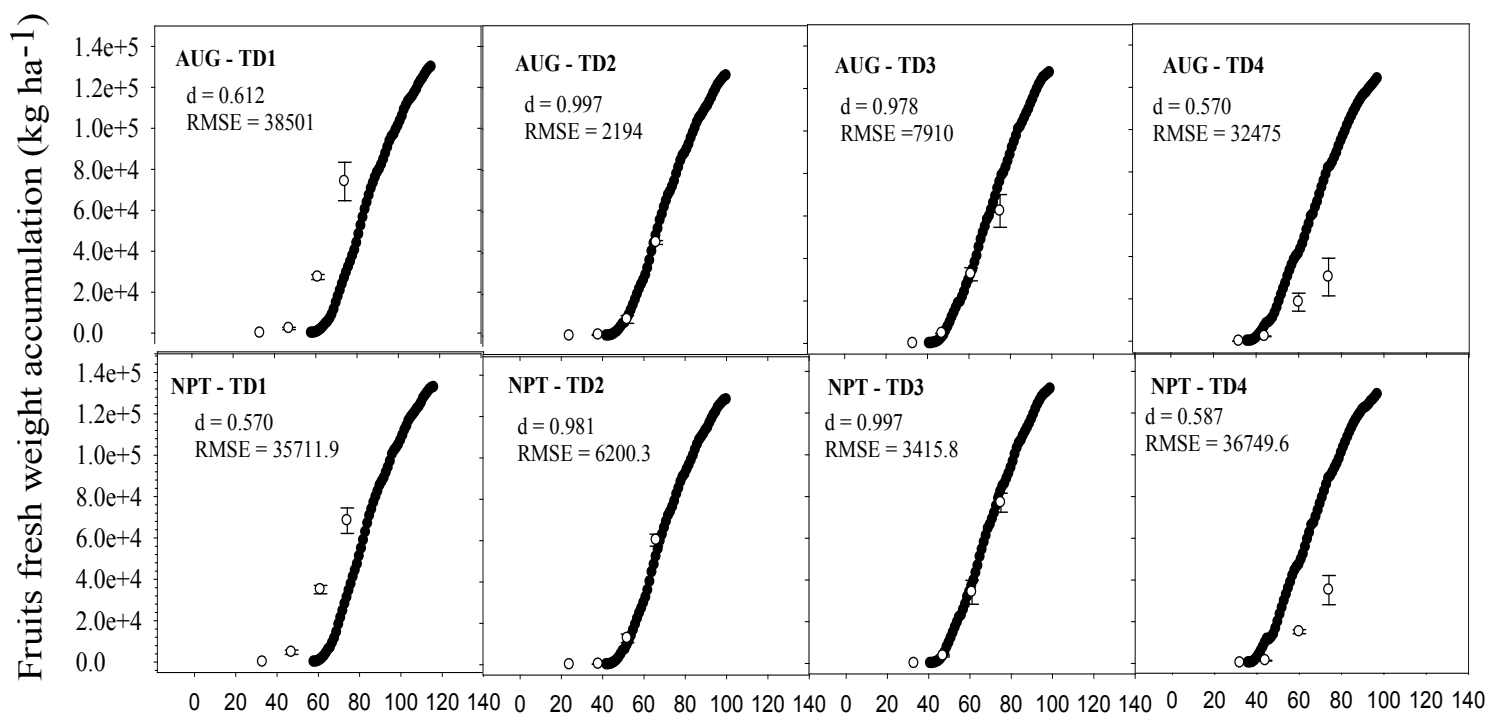

Days after transplanting

- $\quad$ Simulated

- Observed

Fig. 6. Simulated and observed fresh fruits weight accumulation (FFW) for AUG and NPT processing tomato varieties at the four different transplanting dates during the spring 2010 growing season

- Leaf area index (LAI)

Simulation of leaf area index calibration using CSM-CROPGRO-Tomato model in 2009 was relatively low compared to the other growth parameters (Fig. 7). For AUG variety, it was well simulated under TD1 conditions ( 0.922 of d-Stat, and 0.14 of RMSE), whereas it gave unsatisfied simulation under TD2, 3 and 4 conditions, giving d-Stat values of $0.592,0.479$ and 0.768 , respectively; and RMSE values of $0.50,0.73$ and 0.21 , respectively. NPT variety had similar simulation to AUG variety giving $0.924,0.524$, 0.511 and 0.584 as d-Stat values; and giving 0.17 , $0.64,0.76$ and 0.52 as RMSE values for TD1, 2, 3 and 4, respectively (Fig. 7).
In 2010, simulation of leaf area index validation was also low compared with the other growth parameters (Fig. 8). For AUG variety, it was well simulated under TD1 and TD2 conditions ( 0.784 and 0.728 of d-Stat, respectively; and 0.69 and 0.74 of RMSE, respectively), whereas it gave unsatisfied simulation under TD3 and 4 conditions, giving d-Stat values of 0.661 and 0.542 , respectively; and RMSE values of 0.65 and 0.52 , respectively. NPT variety had similar simulation to AUG variety giving $0.862,0.660$, 0.634 and 0.738 of d-Stat values; and giving 0.49 , $1.15,0.75$ and 0.23 as RMSE values for TD1, 2, 3 and 4 , respectively. 


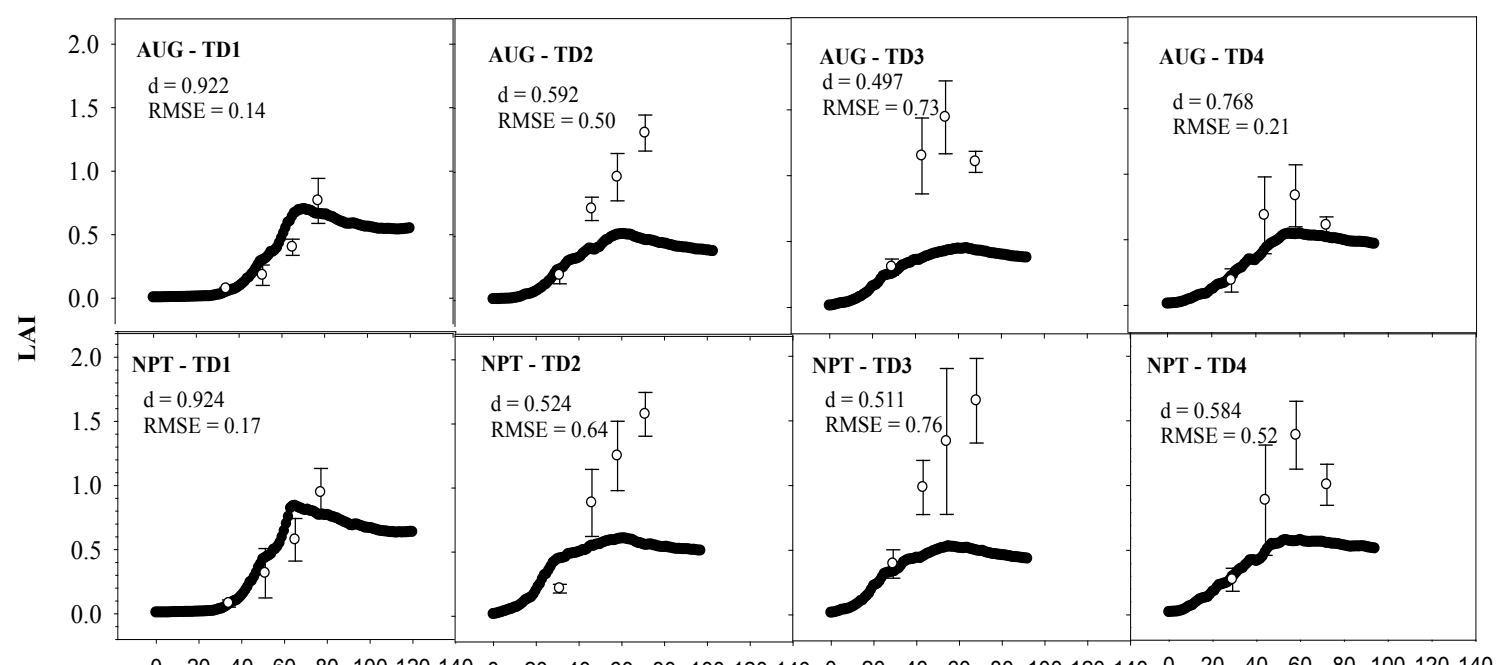

Days after transplanting

- $\quad$ Simulated

- Observed

Fig.7. Simulated and observed leaf area index (LAI) for AUG and NPT processing tomato varieties at the four different transplanting dates during the spring 2009 growing season.

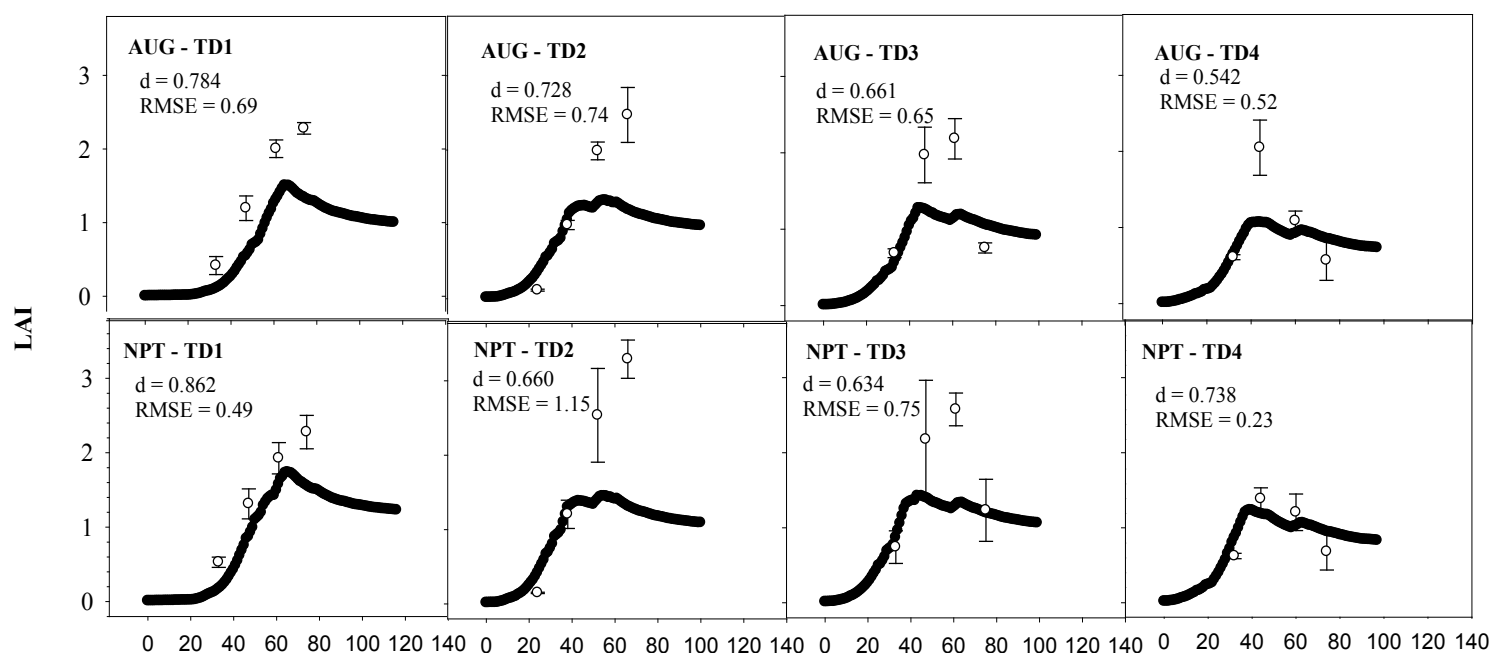

Days after transplanting

- $\quad$ Simulated

- Observed

Fig. 8. Simulated and observed leaf area index (LAI) for AUG and NPT processing tomato varieties at the four Discussion different transplanting dates during the spring 2010 growing season

The difference between results of the two years was due to different weather conditions. In 2009 , the precipitation amounts during growth cycle were 178, 246, 286 and $276 \mathrm{~mm}$ from TD1 to TD4, respectively, whereas in 2010 they were 274, 317, 305 and $314 \mathrm{~mm}$ from TD1 to TD4, respectively. Precipitation frequency was more in 2010 than in 2009 with an average of 10 days. These differences gave better conditions in 2010 
to have better yield. The average temperature in 2009 was between 16 and $20^{\circ} \mathrm{C}$, while in 2010 average temperature was between 20.5 to $22^{\circ} \mathrm{C}$ during the growing cycle. Higher temperature in 2010 favor also plant growth, development, and yield, consequently.

Better yield has been observed for earlier transplanting dates reflects the enhancement of weather conditions in earlier transplanting dates than the late ones. NPT 63 variety showed vigor vegetative growth which is a part of its genetic characteristics when compared to AUG variety. Since the season was relatively cold and wet during different growth stages, so soil water retention was unique for almost the entire experimental site and mulching the soil didn't give a significant effect on water use efficiency. Reduction of water use efficiency differences between varieties as well as transplanting dates was due to the rainy season in almost all the period of plant growth, hence, the irrigation amount and period were very limited.

CSM-CROPGRO-Tomato model ability to simulate growth development and yield was relatively high due to its tools that are allowing the user to adjust its parameters using sensitivity analysis and obtaining the genetic coefficients really represents plant growth stages. Obtaining high d-Stat values between observed and simulated total dry matter accumulation, yield, harvest index and other parameters gives an indication about visibility of using this model at a wider scale.

Simulated LAI fitted the measured data during the initial growth as shown by a slow increasing of LAI due to the transplant shock coupled with the crop being source limited due to incomplete light interception. Thereafter, the fit was less perfect possibly due to large variability in the observed data. These results were in accordance with Scholberg et al. (1997) who is the developer of CSM-CROPGRO-Tomato for open field conditions. They were also consistent with Rinaldi et al. (2007) findings who found that simulated LAI increased slower than measured ones probably because the model does not consider the twin rows plant distribution and overestimates the competition for light among plants.

Calibration process resulted in: model efficiently simulated the total plant dry matter, fruits fresh and dry weight, and harvest index; then it acceptably simulated the vegetative dry weight and number of fruits, while it poorly simulated leaf area index of field-grown processing tomato for the two varieties under study. First transplanting date had low simulation efficiency compared to other transplanting dates.

Validation process confirmed that the efficiency of the model simulation was: high for total plant dry matter, fruits fresh and dry weight, and harvest index; medium for vegetative dry weight and number of fruits, and low for leaf area index of field-grown processing tomato for the two varieties under study. It also confirmed that first transplanting date had low simulation efficiency compared with other transplanting dates.

\section{Conclusions}

Evaluating NPT 63 variety under both soil management conditions, this variety is recommended for processing tomato growers due to its vigor characteristics. Plants of this variety gave higher dry biomass accumulation as well as yield compared with AUG variety studied. This recommends it as a resistant variety against weeds competition and diseases. In addition to growth advantages, it gave also better qualitative yield (more red fruits than rotted fruits), which favor it also in terms of storage, processing, conservation, and qualitative concerns in the final product.

Under moderate rainy season, mulching the soil is a useful tool to decrease plant water consumption levels and increasing yield and water use efficiency at the transplanting dates studied. The effect of mulching the soil was great due to decreasing soil water evaporation, increasing soil water retention, and increasing the rate of root growth. Under rainy season (as the case in 2010), mulching the soil is an added cost without ameliorating yield comparing to non-mulched conditions. This finding is due to the homogenity of water distribution throghout the soil area which balanced the water uptake between the two soil managments, in addition to relatively low temperature duing the rainy season at summer time which correspondly decreased the soil water evaporation even under non-mulched conditions.

The validation of the model following calibration showed a good performance of simulated values comparing with the observed data. The model simulated yield very well for the second, third, and forth planting dates for both 
varieties. This indicates that under northeastern Italian conditions it would be possible to use the model and to simulate the possible yield of different processing tomato varieties and different seasonal and weather conditions.

Using the two years' datasets of different weather conditions to calibrate and validate the model confirmed the use potential of this model to be utilized as a decision-making tool for both farmers and decision makers at the regional level. Weather conditions were different along the growing seasons of 2009 and 2010, giving semidry season in 2009 and humid season in 2010. These differences had more reliable effects on plant response, but the model could follow this response and it predicted it adequately in both seasons. This indicates that under northeastern Italian conditions it would be possible to use the model and to simulate the possible yield of the different processing tomato varieties and different seasonal and weather conditions.

To evaluate the simulation capability of the model for a larger range of conditions, further work should be done regarding the genotype coefficients for each variety under study. CSMCROPGRO-Tomato model is not yet designed for mulched conditions and further studies should be done in this regard as well. CSM-CROPGROTomato simulation model could be used as a decision-making tool helping in the regional short term plans. Other tomato varieties could be taken into consideration to calibrate the model also for other environmental and agronomic conditions.

\section{Acknowledgements}

We would like to express our appreciation to the Italian Ministry of Foreign Affairs for its financial support, and to staff of the Dept. of Biological and Agricultural Engineering, the University of Georgia, USA, for providing DSSAT v4.5 software, and for scientific and technical support.

\section{References}

Bertin, N. and Gray, C. (1993) Tomato fruit set: A case study for validation of the model, TOMGRO. Acta Horticulturae, 328, 185-193.

Boote, K.J., Jones, J.W. and Hoogenboom, G. (1998a) Simulation of crop growth: CROPGRO model.
In: Peart, R.M., Curry, R.B. (Ed.), Agricultural Systems Modeling and Simulation (Chapter 18). Marcel Dekker, Inc, New York, pp. 651-692.

Boote, K.J., Jones, J.W., Hoogenboom, G. and Pickering, N.B. (1998b) The CROPGRO model for grain legumes. In: Tsuji, G.Y., Hoogenboom, G., Thornton, P.K. (Ed.), Understanding Options for Agricultural Production. Kluwer Academic Publishers, Dordrecht, pp. 99-128.

Food and Agriculture Organization of the United Nations Rome, (2007) Interdepartmental-working group on climate change.

Food and Agriculture Organization of the United Nations Rome (2009) http://faostat.fao.org/default. aspx

Heuvelink, E. and Marcelis, L.F.M. (1989) Dry matter distribution in tomato and cucumber. Acta Horticulturae, 260, 149-157.

Hoogenboom, G., White, J.W., Jones, J.W., Boote, K.J., (1994) BEANGRO: A process-oriented dry bean model with a versatile user interface. Agronomy Journal, 86, 182-190.

Hoogenboom, G. and White, J.W. (2003) Improving physiological assumptions of simulation models by using gene-based approaches. Agronomy Journal, $95(1), 82-89$.

Hoogenboom, G., Jones, J.W., Wilkens, P.W., Porter, C.H., Boote, K.J., Hunt, L.A., Singh, U., Lizaso, J.L., White, J.W., Uryasev, O., Royce, F.S., Ogoshi, R., Gijsman, A.J. and Tsuji, G.Y. (2009) Decision Support System for Agrotechnology Transfer (DSSAT) Version 4.5 [CD-ROM]. University of Hawaii, Honolulu, Hawaii.

Hunt, L.A., White, J.W. and Hoogenboom, G. (2001) Agronomic data: Advances in documentation and protocols for exchange and use. Agricultural Systems, 70, 477-492.

Jones, J.W., Dayan, E., Allen,L.H., van Keulen, H. and Challa, H. (1989) Modeling tomato growth for optimizing greenhouse temperatures and carbon dioxide concentrations. Acta Horticulturae 248, 285-294.

Jones, J.W., Dayan, E. Allen,L.H. van Keulen, H. and Challa, H. (1991) A dynamic tomato growth and

Egypt. J. Soil Sci., Vol. 57, No.4 (2017) 
yield model (TOMGRO). Trans. Am. Soc. Agric. Engr. (ASAE) 34, 663-672.

Jones, J.W., Tsuji, G.Y., Hoogenboom, G., Hunt, L.A., Thornton, P.K., Wilkens, P.W., Imamura, D.T., Bowen, W.T. and Singh, U. (1998) Decision support system for agrotechnology transfer; DSSAT v3. In: Tsuji, G.Y., Hoogenboom, G., Thornton, P.K. (Ed.), Understanding Options for Agricultural Production. Kluwer Academic Publishers, Dordrecht, the Netherlands, pp. 157177.

Jones, J.W., Hoogenboom, G., Porter,C.H., Boote, K.J., Batchelor, W.D., Hunt, L.A., Wilkens, P.W., Singh, U., Gijsman, A.J. and Ritchie, J.T. (2003)DSSAT Cropping System Model. European Journal of Agronomy, 18, 235-265.

Loague, K. and Green, R.E. (1991) Statistical and graphical methods for evaluating solute transport models: overview and application. J. Contam. Hydrol., 7, 51-73.

Pimpini, F., Enzo, M. and Lazzarin R. (2004) Soluzione nutritive. p.107-138. In: Enzo M., Gianquinto G., Lazzarin R., Pimpini F. and Sambo P. (Ed.), Prinicipi Tecnico-Agronomici della Fertirrigazione e del Fuori Suolo. Veneto Agricoltura, Legnaro (PD), Italy.

Rinaldi, M., Ventrella, D. and Gagliano, C. (2007) Comparison of Nitrogen and Irrigation Strategies in Tomato Using CROPGRO Model, a Case Study from Southern Italy. Agricultural Water Managment, 87, 91-05.
Scholberg, J.M.S., Boote, K.J., Jones, J.W. and McNeal, B.L. (1997) Adaptation of the CROPGRO model to simulate the growth of field-grown tomato. In: Kropff, M.J. et al. (Ed.) Systems Approaches for Sustainable Agricultural Development: Applications of Systems Approaches at the Field Level. Kluwer Academic Publishers, Dordrecht, The Netherlands, pp. 133-151.

Uehara, G. (1989) Technology transfer in the tropics. Outlook Agricultural, 18, 38 /42.

Willmott, C.J. (1982) Some comments on the evaluation of model performance. Bull. Am. Meteorol. Soc. 63, 1309-1313.

Willmott, C. J., ackleson, S. G., davis, R. E., feddema, J. J., klink, k. M., legates, d. R., o'connell, J. and Rowe, C.M. (1985) Statistics for the evaluation and comparison of models. Journal of Geophysical Research, 90, 8995-9005.

Wolf, S., Rudich, J., Marani, A. and Rekah,Y. (1986) Predicting harvesting date of processing tomatoes by a simulation model. J. Am. Soc. Hort. Sci. 111, 11-16.

World Processing Tomato Council (2006) AMITOM Report. http://www.wptc.to/rele.

(Received: $27 / 12 / 2016)$

accepted: 10 / 8 /2017) 


\section{تقيبم تأثير تاريخ الشتل على إنتاج طماطم التصنيع (ليكوبرسيكون إسكولنتوم ميل.)

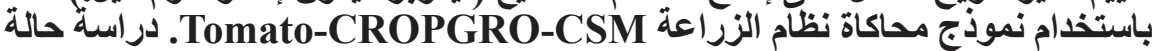 \\ لثمال شرق إيطاليا

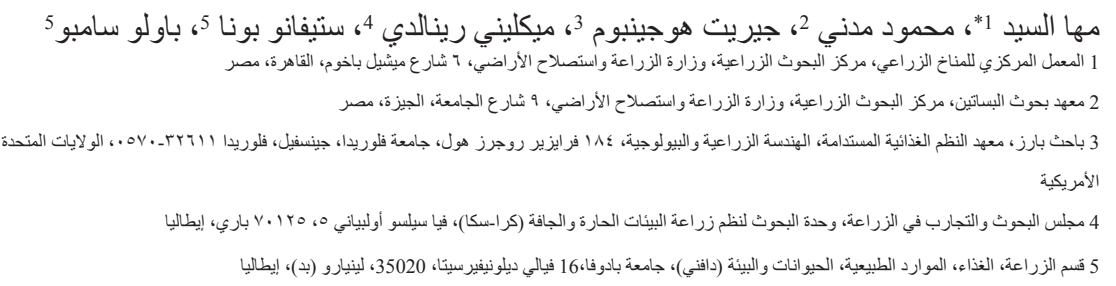

تعتبر الطماطم الإيطالية المصنعة ذات هيمنة كبيرة على المستوى العالمي، إلا أنه يوجد دراسات قليلة على هذا المحصول باستخدام نهج تحليل نظم المحاصيل. وكان

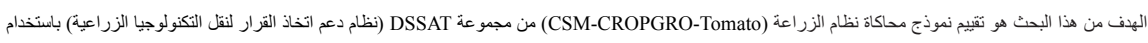

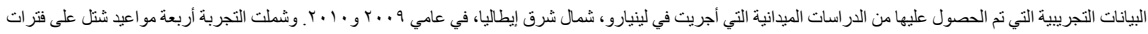

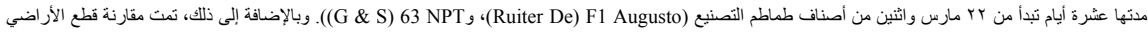

المغطاة وغير المغطاة بشر ائح البلاستيك الأسود. وأظهرت المقارنة بين كمية المحصول لمو اعيد الثنتل المختلفة أن الززراعة في وقت مبكر أدت إلى زيادة كمية المحصول لكلا الصنفين.

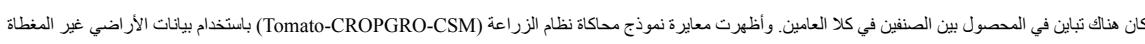

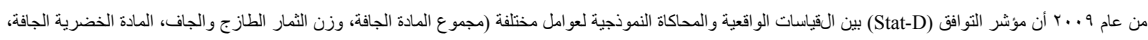

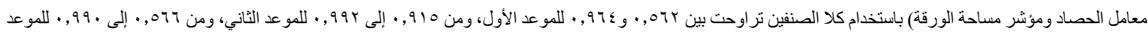

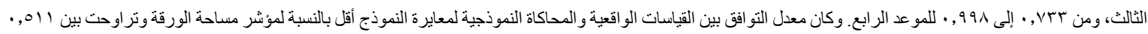

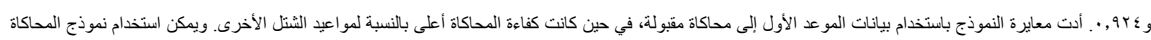

كأداة للمساهمة في صنع القرار واللمساعدة في الخطط الإقليمية قصيرة الأجل. 